\title{
ASSESSMENT OF POSTERIOR WATERPROOFING OF THICK-BRICK-WALLS
}

Gergő Vinczlér ${ }^{1}$

Annamária Dudás ${ }^{2}$

Valéria V. Horn ${ }^{3}$

UDK: 699,82

DOI:10.14415/konferencijaGFS2017.043

Summary: Until the beginning of the 20th century protection against moisture of buildings has not been solved. The technologies of posterior waterproofing are confined for more than 60-cms-thick brick walls. The chemical injection supplemented with waterproofing slurry and restoration plaster provide a complex technology, but often not all these techniques are realized. The article assesses the versions from technical and economical point of views based on life expectancy and return. The comparison gives evaluation of reconstruction solutions.

Keywords: reconstruction, posterior waterproofing, injection, restoration plaster

\section{INTRODUCTION}

During construction of posterior waterproofing the consideration for system solution is essential. Regardless of the technologies the prevention of masonry wetting by capillary rising, the construction of surface waterproofing and the application of renovation plasters are both important elements of the technically complex solution. [1-4] Usually the combination of these techniques gives the most durable result. However, in most cases the costs determine what would be realized from the listed constructions during posterior waterproofing works. Often a compromise is reached, at which several points to be considered. This article presents the possible combinations of the mentioned technologies on a common building construction detail of the $19^{\text {th }}$ and $20^{\text {th }}$ century downtown buildings in Budapest. [1] Typical thickness of small-size-brick masonry exceeds $60 \mathrm{~cm}$, depending on the numbers of floors of the building it rises up to $1 \mathrm{~m}$ thickness. [5, 6] These building details contacted to the soil are exposed to high level of moisture load caused by the undeveloped methods of insulation or the lack of water insulation, due to the continuing

\footnotetext{
${ }^{1}$ Gergő Vinczlér, MSc civil eng., H-1116 Budapest, Hunyadi J. street 162. Hungary, tel: +361204 35 16, e mail: gergo.vinczler@gmail.com

${ }^{2}$ Annamária Dudás, PhD. civil eng., associate professor of Budapest University of Technology and Economics, Faculty of Civil Engineering, Department of Construction Materials and Technologies, H-1111 Budapest, Hungary, tel: +36146323 73, e - mail: dudas.annamaria@epito.bme.hu

${ }^{3}$ Valéria V. Horn, DLA, architect, assistant professor of Budapest University of Technology and Economics, Faculty of Civil Engineering, Department of Construction Materials and Technologies, H-1111 Budapest, Hungary, tel: +36146323 73, e - mail: horn.valeria@epito.bme.hu
} 
existence, or even increasing moisture effects. [7-9] Without appropriate provisions these effects can cause significant damage to buildings. [10]

\section{APPLIED TECHNOLOGIES}

\section{Renovation plaster}

Applying of renovation plaster system does not protect against moisture, however often developed as particular application, thus it might seem economical solution as one-time investment. Because the moisture supply is not eliminated, the saltcrystal formation decreases the vapour permeability of the plaster over time, so the efficiency of them also.[11]

\section{Chemical injection}

With chemical injection the rising moisture in the capillaries of the masonry is prevented. The injection materials varies widely, thus their effect is also different. Such substances are primarily recommended which protect the structure in various methods besides the realization of complex chemical reactions. The material used in this assessment is alkali silicate-siliconate, which has pore restricting and also hydrophobic effect in the inner surface of capillaries.

After the formation of the water barrier layer the moisture could be concentrated under the injection zone, which continue to be spread toward surfaces with lower resistance. It is important to take into consideration the departure of the remaining moisture above the injection level, which can only be ensured in an appropriate form without the use of restoration plasters if existing plaster of the walls is removed. However, the drying of the remaining raw walls may take up to 12-18 months.

The injection technology is fundamentally influenced by the thickness of the walls to be treated. Following the general principles, it can be stated that up to $60-\mathrm{cm}$-width one sided, while for wider walls two-sided drilling and borehole arrangement is required.

\section{Waterproofing slurries}

At the application of smeard insulations fundamental distinction must be made between internal and external side application. Greater caution must be taken to the negative side wall and floor insulation, hence the material of the substrate structure remaining moist in this case. This means that an intermediate insulating layer is needed, which is resistant to negative side water pressure, and has adequate adhesion to the original structure. General case is when insulation should be developed on an uneven, rough brick wall. In this case firstly an equalization layer is necessary, but it shall be taken into account that the substance used to smoothing the surface, which is able to maintain its strength and adhesion characteristics on a wet medium. The necessary consumption and number of layers of used materials are determined in each case by the degree of moisture load. Essential parts of the waterproofing system are the reinforcing joint tapes and the elements used in pipe penetrations.

The use of surface insulation inside, as an individual insulation, is impractical. As a result of applying insulation coating a vapour breaking or in particular cases a vapour barrier layer is formed, which causes that the moisture in the masonry can not evaporate into the direction of premises. As a result of it, the accumulated moisture in the structure is rising higher. This can present meter-dimension height in function of moisture load. 
Contemporary achievements in civil engineering 21. April 2017. Subotica, SERBIA

\section{COMBINATIONS}

\section{Renovation plaster}

The separated application of renovation plaster in case of increased moisture load assessed to be a temporary solution, because of the constant moisture and structure damaging salts the material of internal structure is saturated, thus service life is reduced. At the same time their role is excessively important as an additional element to the insulation coating and chemical injection, because it helps in the drying of the walls and plays a role in humidity management of the room (Figure 1).

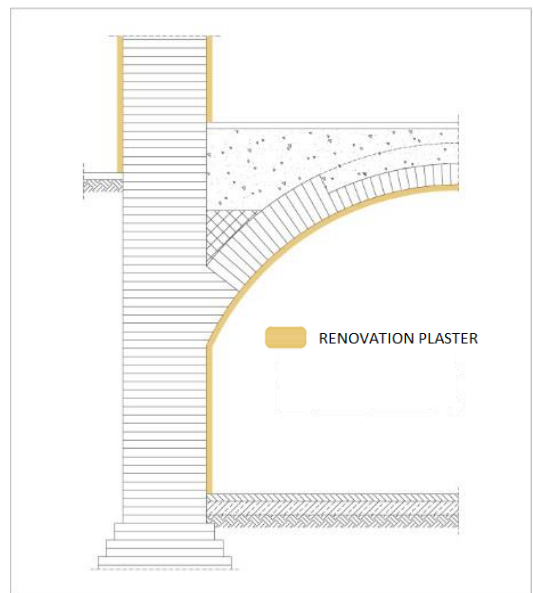

Figure 1. Renovation plaster on the basement and ground floor walls

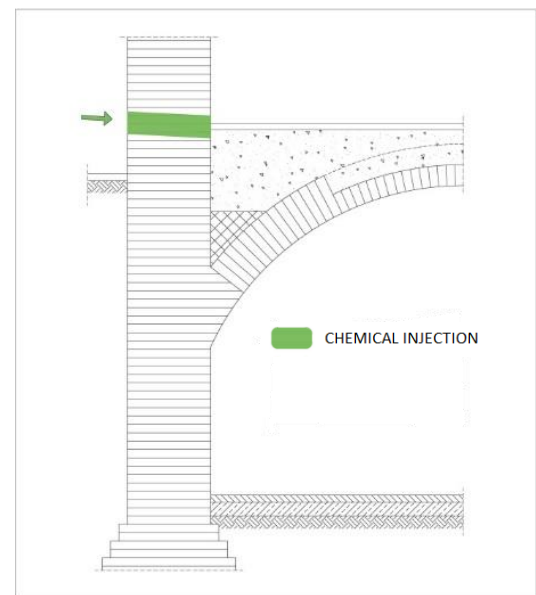

Figure 2. Injection at the floor level of ground floors

\section{Chemical injection}

The separated application of injection insulation on the basement level is generally impractical because the moisture coming from the direction of foundation could be cut, but the wall still remains wet due to the dampening effect of the soil surrounding the basement wall. Using only injection technology to protect the walls could be realized by the mass injection method, but from cost-effective point of view it is not considered as a realistic option. If injected solution is realized the continuity must be particularly taken into consideration, for example at the supporting of the voults $[7,8]$, but at the same time the load-bearing aspects must not be ignored.

If only ensuring of the moisture protection of ground floor units is the goal for buildings with basement, then injection at the level of slab of the ground floor can be performed (Figure 2). In case of external side borehole arrangement the posterior insulation is feasible without demolishing of internal areas, on the condition of existing floors insulation is in good condition. In cases where this latter condition is not fulfilled or in the floor there is absolutely no insulation, special attention should be paid during the renovations.

During the design and the construction of chemical injection insulations the 6-9 weeks technological time should be taken into account, during the chemical reactions that take place completely. 


\section{Waterproofing slurry and renovation plaster}

The combination of the smeard insulation with waterproofing slurry and the renovation plaster eventuates a compromised solution. At the same time temporary treatment of the above-described phenomenon of moisture migration is solved by the high pore-rate surface renovation plaster system.

In case of renovation works when the aim is the utilization of basement, and if the external site excavation is not possible, the negative side insulation must be developed on the walls and floors equally. An important aspect in addition to the increase in capillary absorption is that the applied renovation plaster system is not able to participate in the facilitating of masonry evaporation, hence the underlying waterproofing is firmly vapour breaking. The function of the restoration plaster on the negative side waterproofing is the prevention of vapour precipitation from the air on the surfaces.

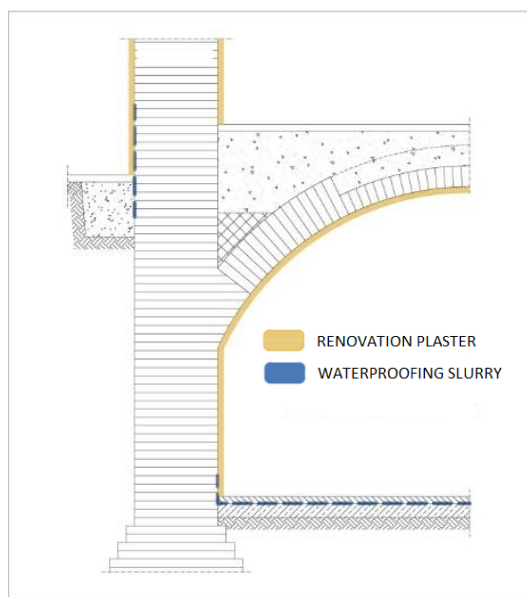

Figure 3. Waterproofing slurry and renovation plaster

Application of insulation coating at the ground floor supplemented with renovation plaster can be an effective solution in situations where significant proportion of moisture results from rainwater splashing on the skirting or because the counter slope of the pavement drives the water into the walls. In these cases the skirting insulation greatly helps to reduce the level of humidity in the room. However, the basement moisture from the structure at the skirting level would be unable to evaporate, if this is a large amount, thus it may occur on the inner side of the walls or on the floor.

For this insulation version the design life of the system is determined by the renovation plaster. Without the prevention of capillary rising the moisture load is constant, thus may need to be renovated repeatedly in few years.

\section{Chemical injection and waterproofing slurry}

This is the first combination, which prevents both wetting of surface and capillary rising. Co-application of the injection and surface coating insulation from underground and skirting insulation is also provided.

\section{6} | ЗБОРНИК РАДОВА МЕЂУНАРОДНЕ КОНФЕРЕНЦИЈЕ (2017) | 
Contemporary achievements in civil engineering 21. April 2017. Subotica, SERBIA

Figure 4 shows that the posterior waterproofing of the structures to be protected is feasible by complex methods. However, ensuring the dryness of the masonry is important after the injection and the smeard insulation, because significant moisture is still in the masonry. Otherwise, the remaining moisture can cause further damages (e.g. flaking of plaster, molding, etc.).

Without the use of renovation plaster the total drying time of walls is greatly affected by the thickness of the wall, the type of plaster and the paint also, but it could be up to 18 months. This dramatically extends the necessary renovation technology and construction time. Optional solution is building an independent wall lining, however it reduces the usable interior space. In the air gap, which is formed between the lining wall and the basement wall, a mechanical ventilation should be established, that is ventilated out to outside air.

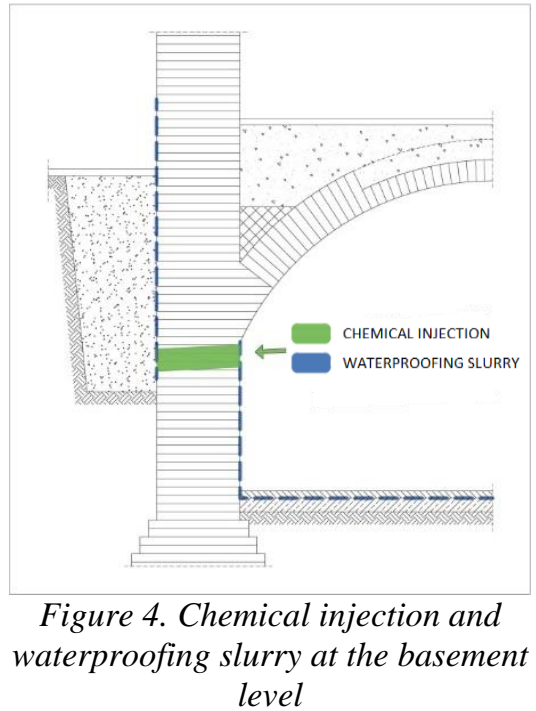

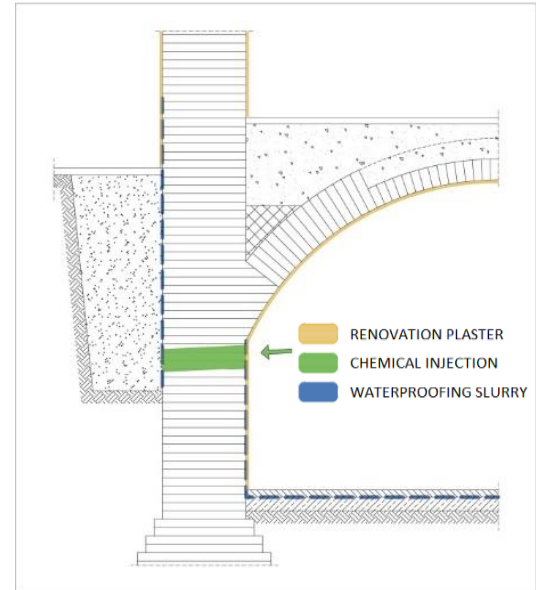

Figure 5. Chemical injection, waterproofing slurry and renovation plaster at the basement level

\section{Chemical injection, waterproofing slurry and renovation plaster}

A technically complete solution is given with the combination of injection, the insulation coating and the renovation plaster. The technological characteristics are the same that described in the preceding paragraphs. Thanks to the combination of materials protection against the rising moisture from the soil next to the wall and from rainwater soaking are both achieved. In addition, renovation plaster helps the humidity management of building structures and facilities, also the drying of protected components and the storage of the building damaging salts. [12]

\section{The posterior waterproofing of walls thicker than $60 \mathrm{~cm}$}

For walls thicker than $60 \mathrm{~cm}$ the injection carries more uncertainty:

- Creating long, even more than 1 meter boreholes is difficult in damp walls.

- Cleaning of the boreholes can not be performed properly. 
- The sufficient spread of injection material can not be guaranteed.

- The continuity of the water-tight zone is uncertain despite of enough substance absorbed because of the uncertain connection of material spreading from the opposite boreholes.

In these cases the boreholes have to be prepared from both sides of the wall. Determination of the proper height and the angle for borehole is important especially because of the external and the internal plane of borehole arrangement differ, the adequate water-tight zone does not develop during installation. The posterior waterproofing of thick-brickwalls requires different methods only in respect to the injection compared to those technologies described above.

\section{THE COMPARISON OF THE COMBINATIONS}

As in the previous section were also presented, the different versions provide solutions altering in durability. In addition, the process of the implementation is also distinct, and the wet/dry structural rate develops differently as well.

The comparison of the solutions can not be interpreted on the basis of one criterion because many aspects need to be considered before their application. It is important to take into account the technical, the durability, the technological and the economic views equally, because the correct conclusion can be drawn only in this way. The following analysis compares the different alternatives using these viewpoints.

The ratings are based on a scale ranging from 1 to 5 . A higher rating does not necessarily mean a more positive evaluation. Following the classification aspects:

- Complexity: The complexity refers to the technical wholeness, so the higher value of the scale also means a technically more complex solution.

- Multiplicity: The multiplicity includes the number of the tools and procedures necessary for the application of the technology, so the higher value of the scale indicates a greater demand of machines and labour.

- Technological time: A higher value of the scale signs a longer process time. It is important to separate the technological and construction time.

- Construction time: The construction time includes that period, which is necessary to realize the combinations. The higher value of the scale means a longer process time. The definition of exact service life of the renovation versions is not possible. However, the lower and upper limits of the expected life time can be estimated on the basis of empirical data. It is important to note that the values given are not fixed, the conditions may affect their evolution. During the analysis of the combinations, the expected lifetime of the systems was defined by the service life of the least durable material.

The comparison of the versions is not applicable using prices versus square meters, because the individual system components are utilized in different amounts (e.g. the waterproofing slurry can be used on the wall and on the floor as well, but the restoration plaster is only applied on the wall surface).

The economical values shown in the Table 1 were calculated by using a unit length of the structural section of the Figure 1-5.

For reasons of comparability, the costs are presented in percentage form. The basis for the comparison, as the value for $100 \%$ belongs in each case to the version associated with the highest cost. 
Contemporary achievements in civil engineering 21. April 2017. Subotica, SERBIA

Table 1. Comparison of the versions

\begin{tabular}{|c|c|c|c|c|c|c|}
\hline & \multicolumn{5}{|c|}{ RENOVATION VERSIONS } \\
\hline & & I. & II. & III. & IV. & V. \\
\hline & & $\begin{array}{l}\text { Renovation } \\
\text { plaster }\end{array}$ & $\begin{array}{l}\text { Chemical } \\
\text { injection }\end{array}$ & $\begin{array}{l}\text { Waterproofing } \\
\text { slurry and } \\
\text { renovation plaster }\end{array}$ & $\begin{array}{c}\text { Chemical injection } \\
\text { and waterproofing } \\
\text { slurry }\end{array}$ & Full system \\
\hline 导 & $\begin{array}{l}\text { Damp structure } \\
\text { rate }\end{array}$ & $\begin{array}{l}\text { no change / } \\
\text { decrease }\end{array}$ & $\begin{array}{c}\text { no change / } \\
\text { decrease }\end{array}$ & $\begin{array}{c}\text { no change / increase } \\
\text { / decrease }\end{array}$ & decrease & decrease \\
\hline IIIㅂ & Complexity & $1-2$ & 1 & 2 & 4 & 5 \\
\hline ઉ̃ & Multiplicity & 1 & 3 & 2 & 4 & 5 \\
\hline 夏 & $\begin{array}{c}\text { Technological } \\
\text { time }\end{array}$ & 3 & 5 & 4 & 5 & 5 \\
\hline 诖 & $\begin{array}{c}\text { Construction } \\
\text { time }\end{array}$ & 3 & 1 & 4 & 2 & 5 \\
\hline 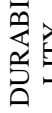 & $\begin{array}{c}\text { Expected service } \\
\text { life }\end{array}$ & $0,1-10$ & $30-35$ & $0,1-10$ & $25-35$ & $25-35$ \\
\hline 它 & $\begin{array}{l}\text { Expected } \\
\text { investment } \\
\text { costs }^{4}\end{array}$ & $82,4 \%$ & $17,1 \%$ & $100,0 \%$ & $42,9 \%$ & $90,0 \%$ \\
\hline $\begin{array}{l}0 \\
\text { o } \\
0 \\
\text { e } \\
\text { II }\end{array}$ & $\begin{array}{l}\text { Comparative } \\
\text { cost during the } \\
\text { same lifetime } \\
\text { (30 years) }\end{array}$ & $82,4 \%{ }^{5}$ & $2,9 \%$ & $100,0 \% 5$ & $7,2 \%$ & $15,0 \%$ \\
\hline
\end{tabular}

In Table 1 it is apparent that the complexity of the variations changes according to the number of technologies. However, looking at the economical side it is clear that the use of one technology can also mean an inefficient solution, e.g. applying the renovation plaster is a significant cost in itself. By analysing the comparative cost during the same lifetime it is clearly visible that the application of the overall system is more economical than the partial solutions.

\section{SUMMARY}

As it was shown in Chapter 4, the rating of the different versions based on various aspects gives dissimilar results. The independent use of the renovation plaster often seems to be a reasonable solution for the users, but it can not be called an optimum concerning durability and economical aspects. In addition, the technical and economical comparison showed that the combined application of waterproofing slurry and renovation plaster is not cost-

\footnotetext{
${ }^{4}$ The values were calculated with valid prices in Hungary in 2016.

${ }^{5}$ Supposing a 5 year expected service life.
} 
effective on long term. The economic comparison describes the expected costs of the different versions regarding the same service life (30 years). The values show that the renovation plaster is the least favourable option (see Figure 6.).

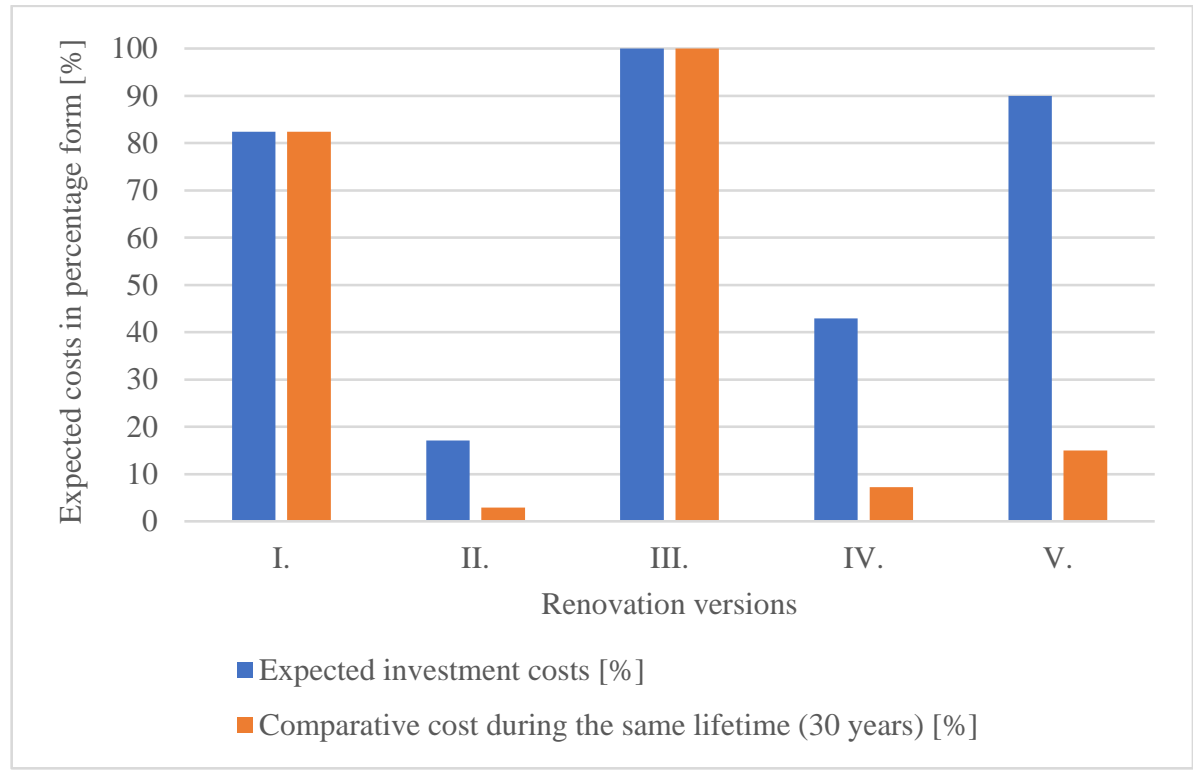

Figure 6. The percentage change of the expected costs

The wetting of the building structure can be prevented completely by applying the waterproofing slurry and the chemical injection system. This version is a long-term and economically efficient solution, but it does not attend to the remaining dampness in the structure. By supplementing with renovation plaster it can be solved, which greatly facilitates the drying of the masonry and the moisture management of the room.

It is generally stated that there is no combination that could be an optimal solution considering all aspects. Applying the whole system leads to a technical complex result, but in terms of cost efficiency it is not always the best version. In financial terms, application of the waterproofing slurry and the chemical injection system is the most favourable (apart from using the latter independently), but the drying of the remaining moisture can only be achieved within months without mechanical ventilation.

Thus, at building reconstruction works the posterior waterproofing should be designed such a complex system, which is an optimal solution taking into account the most aspects at the same time. The priority order of the listed aspects is determined by the field conditions, by the expectations of the owners and by the budget.

\section{REFERENCES}

[1] Vinczlér, G.: Vastag falazatok utólagos vízszigetelésének vizsgálata (Analysis of posterior waterproofing of thick walls), MSc Thesis, manuscript, 2017. 
Contemporary achievements in civil engineering 21. April 2017. Subotica, SERBIA

[2] Balík, M., Starý J.: Pincék felújítása és utólagos vízszigetelése (Restoration and posterior waterproofing of basements), CSER Publisher Ltd., 2008.

[3] Dudás, A.: Talajjal érintkező épületszerkezetek felújítása (Restoration of ground contacted building structures), Magyar Épitéstechnika (Hungarian construction technology), 2012. vol. 4, p.p. 16-21.

[4] Frössel, F.: Falak utólagos víztelenítése és szigetelése (The posterior dewatering and waterproofing of walls), TERC Ltd., 2006.

[5] Pattantyús-Ábrahám, Á.: Boltozatok és kupolák (Arches and domes), TERC Ltd., 2011.

[6] Prof. Frick, O., Prof. Knöll, K.: Baukonstruktionslehre (Buildings' construction lesson), B.G. Teubner, 1927.

[7] Déry, A.: Öt könyv a régi építészetről, 2. kötet: Falak, boltozatok, tagozatok, lépcsők (Five books about the old architecture, Volume 2: Walls, arches, sections, stairs), TERC Ltd., 2010.

[8] Déry, A.: Történeti Szerkezettan (Historical structures), TERC Ltd., 2002.

[9] Osztroluczky, M.: Vízszigetelés (Waterproofing), CSER Publisher Ltd., 2010.

[10] Franzoni, E.: Rising damp removal from historical masonries: A still open challenge, Construction and Building Materials, 2014., vol. 54, p.p. 123-136.

[11] Pavlíková, M., Pavlík, Z., Keppert, M., Černý, R.: Salt transport and storage parameters of renovation plasters and their possible effects on restored buildings' walls, Construction and Building Materials, 2011., vol. 25, p.p. 1205-1212.

[12] Dudás, A., Terjék, A.: Efficiency assessment of posterior waterproofing systems of renovated porous limestone masonry work, Technicki Vjesnik-Technical Gazette, 2015., vol. 22, № 5, p.p. 1225-1236. 